\section{Knowing the Fans Behaviour in Relation To Love of Football Clubs Brands}

\author{
Matheus Frohlich Marquetto ${ }^{\dagger}$ \\ Universidade Federal de Santa Maria \\ Nelson Guilherme Machado Pinto ${ }^{\Omega}$ \\ Universidade Federal de Santa Maria \\ Márcia Zampieri Grohmann ${ }^{*}$ \\ Universidade Federal de Santa Maria \\ Luciana Flores Battistella* \\ Universidade Federal de Santa Maria
}

\section{ABSTRACT}

This paper links brand love and sports management, with the intention to identify the relationship of brand love with their constructs antecedents (self-expression, performance satisfaction and relationship satisfaction) and consequent (behavioral loyalty, attitudinal loyalty and positive word of mouth) and see if the soccer team is a moderating factor in these relationships. The theoretical model was based on Santana (2009) used in a survey with 270 fans of soccer rival teams: Sport Club Internacional and Grêmio Football Portoalegrense. The results were analyzed by Structural Equation Modeling. It was identified that the soccer team is a moderating factor in the relations proposals. Thus, it is concluded that the study showed that sports management should be customized, as each team represents something different for their fans. Managers of sports marketing need first to know what image the team presents and what are the feelings involved.

Keywords: Brand love; Antecedents; Consequents; Soccer; Sports marketing.

\section{INTRODUCTION}

The study of brands comprises a broad range of approaches. In this sense, focuses on engagement with the brand are mentioned (COULTER; PRICE; FEICK, 2003; THOMSON, et al, 2005; O'CASS; CHOY, 2008; GUTHRIE, 2009; SWOBODA, et al, 2009;PRENDRGAST; TSANG; CHAN, 2010; PARK; HWANH; PARK, 2011), brand trust (CHAUDHURI; HOLBROOK, 2001; DELGADO-BALLESTER, et al, 2003; DELGADO-BALLESTER; MUNUERA-ALEMÁN, 2005; SICHTMANN, 2007; YANNOPOULOU, et al, 2011; LAFORET; CHEN, 2012), brand loyalty (YI; JEON, 2003; HOLLEBEEK, 2011; TSAI, 2011; BRAKUS, et al, 2009), among others.

However, a new perspective for understanding the relationship between consumers and brands is the vision of "brand love" (also referred to as emotional involvement with the brand) defined by Carroll and Ahuvia (2006) as "the degree of passionate emotional attachment that a satisfied consumer has regarding a particular brand". The idea behind the term is to incorporate theories about love, coming mainly from psychology to the study of consumer behavior.
Corresponding author:

† Universidade Federal de Santa Maria E-mail: matheusmarquetto@yahoo. com.br

${ }^{\Omega}$ Universidade Federal de Santa Maria E-mail: nelguimachado@hotmail.com $¥$ Universidade Federal de Santa Maria E-mail: marciazg@hotmail.com

* Universidade Federal de Santa Maria

E-mail: luttibattistella@gmail.com

Received: 09/18/2015.

Revised: 10/14/2015.

Accepted: 11/16/2015.

Published Online: 02/01/2017. 
According to Albert, Merunka, Valette-Florence (2008) this view is still little explored, but some studies already stand out, such as: Whang, Sahoury and Zhang (2004); Thomson, MacInnis and Park (2005); Carroll and Ahuvia (2006); Albert, et al (2008); Pang, Keh and Peng (2009); Grisaffe and Nguyen (2009); Albert, et al (2009) and Bergkvist and BenchLarsen (2010). In Brazil, few studies have worked with this focus, among which are the studies by Santana (2009); Correia (2009) and Fantini, et al (2011). This shows a clear gap of national studies on brand love.

On the other hand, even though Brazil is popularly known as "the country of football", recently the big teams began to incorporate more professional management mechanisms. Unlike other countries such as the United States and Australia, where scientific studies on sports marketing are common, in Brazil this practice is still incipient (SANTANA, 2009).

The football market generates millions in revenue and to have a clear picture of the magnitude of these values, Capelo (2015) states that in 2014 the Gross Domestic Product (GDP) in Brazil increased by $0.1 \%$ whilst the total revenue of the top 25 teams in the country increased by 7\%, from 2.58 (BRL) billion in 2013 to 2.77 (BRL) billion in 2014. The author further states that this also occurs in other countries. According to Capelo (2015): "clubs revenues worldwide grew in 2014; in percentage it was above the Gross Domestic Product (GDP) of each country".

For comparison purposes, in Spain, in the midst of a severe economic crisis and high unemployment rate, the GDP increased 1.4\% in 2014, the revenue of the 23 teams in the country however, $7 \%$, going from $€ 1.7$ billion to $€ 1.82$ billion. In Italy, where the GDP fell by $0.4 \%$ in 2014 , the revenue of clubs grew by $1 \%$, from $€ 1.16$ billion to $€ 1.17$ billion (CAPELO, 2015). By being aware of the economic and social importance of sports, the academy has created a series of specific journals to address the issue, for example: European Sport Management Quarterly; International Journal of Sport Management, Recreation and Tourism; International Journal of Sport Management; Journal of Sport Management; Sports Management Review; etc.

Thus, we can see a paradox at the time that such a promising market does not receive due attention from the national academy. Given this reality, this article seeks to unite the two aforementioned themes: brand love and the domestic consumer market of football.

We emphasize that this study was guided by Santana (2009)'s work with the addition of the choice of the football team as a moderating factor. Thus, we used one of the greatest rivalries in the country, comparing fans of the two great teams of Rio Grande do Sul state: Sport Club Internacional and Grêmio Futebol Portoalegrense.

The research problem was defined as: what is the impact of the choice of the football team in the relationship between the brand love and their antecedents and consequents constructs? In order to find an answer to this problem, the following objectives were defined: to identify the relationship of brand love with its constructs antecedents (self-expression, satisfaction with the performance, satisfaction with the relationship); to test the relationship between brand love and its constructs consequents (behavioral loyalty, attitudinal loyalty and positive word of mouth); to verify the impact of the football team in the brand love relationship with its antecedents and consequents constructs.

\section{THEORETICAL FRAMEWORK}

The idea that consumers can "love" goods was the initial argument to incorporate this concept to marketing studies. Shimp and Madden (1988) pioneered these studies and were guided by the assumption that the consumer's relationship with an object derived from three aspects: preference, desire, decision/commitment. Another prominent author of this theme was Ahuvia (2005) who, through his interpretative paradigm, identified consumers who have an intense emotional involvement with some objects they loved. His findings 
were later corroborated by Whang, Sahourym and Zhang (2004); Thomson, MacInnis and Park (2005), among others.

As a result of these research on love for objects, studies emerged feelings of love, desire and relationship of consumers with brands (CARROL; AHUVIA, 2006). That is, the perception of loving an object was expanded to loving a brand.

One of the most commonly used definitions on the subject comes from Carroll and Ahuvia (2006) who conceptualize brand love as a passionate and emotional involvement that a consumer has for the brand. The idea according to Hirschman and Holbrook (1982), originates from hedonism that generates consumers more (or less) passionate about brands of the objects they acquire.

Carroll and Ahuvia (2006) also highlight the following properties of brand love : it increases the understanding and the prediction of post-consumer behavior; it is a powerful emotional experience filled of affection; it helps building and maintaining the identity of an individual;and its opposite is not brand hate, but the absence of emotional response to the brand.

Brand love is different from brand satisfaction, because we can love without being (fully) satisfied (CARROLL; AHUVIA, 2006). Similarly, according to Seligman, Fazio and Zanna (1980), loving is not the same thing than having affection, because it involves deeper and longer lasting feelings.

There is no full agreement on the constructs composing brand love; Keh, Pang and Peng (2007), for example, argue that it has three core components: intimacy with the brand, passion for the brand and commitment to the brand. Ahuvia (2005) believes that brand love includes: passion for the brand, attachment to the brand, positive evaluation of the brand, positive emotion generated by the brand and declaration of love for the brand.

In this study, we chose to use the model adapted and validated by Santana (2009) whose focus is towards brand love in soccer teams. For this purpose, the author considers that the antecedents to brand love are: self-expression of the brand and satisfaction with the performance and satisfaction with the relationship. The resulting constructs of brand love are: behavioral loyalty, attitudinal loyalty and positive word of mouth.

Each one of these constructs and their relationship with brand love are explained with the theoretical justification of the hypotheses, presented next and summarized in Figure 1. Subsequently, Figure 2 shows the models used for the measurement of each construct, as well as the original authors and the affirmatives duly adapted for the context of brand love of the football team.

The self-expressive brand is the perception that the consumer has of how a particular brand can increase or reflect their social or inner self (CARROL; AHUVIA, 2006). Their relationship with love focuses on the idea of building and maintaining the identity in the sense that love interferes with the perception of one's self (ARON; PARIS; ARON, 1995).

By expanding this view, research shows that this assumption affects choice of objects (KLEINE; KLEINE; ALLEN, 1995) in the consumer relationship with the brand (FOURNIER, 1998) and in love to the object (AHUVIA, 2005). In perceiving that normally, we love what represents us, we define the first hypothesis of this study as:

- H1: The self-expression of the brand directly and positively affects brand love.

Fournier and Mink (1999) clearly relate brand love with the level of satisfaction when cataloging five types of satisfaction one of which is "satisfaction as love", understood as something that goes beyond joy or pleasure and leads consumers to have a close and quality relationship with the product.

One form of satisfaction is with the relationship, conceived as a general assessment of the purchase and consumption experience to the present time (JOHNSON; ANDERSON; FORNELL, 1995), thus having a long term effect and not merely momentarily. Another form of satisfaction is with the performance, which focuses on performance. 


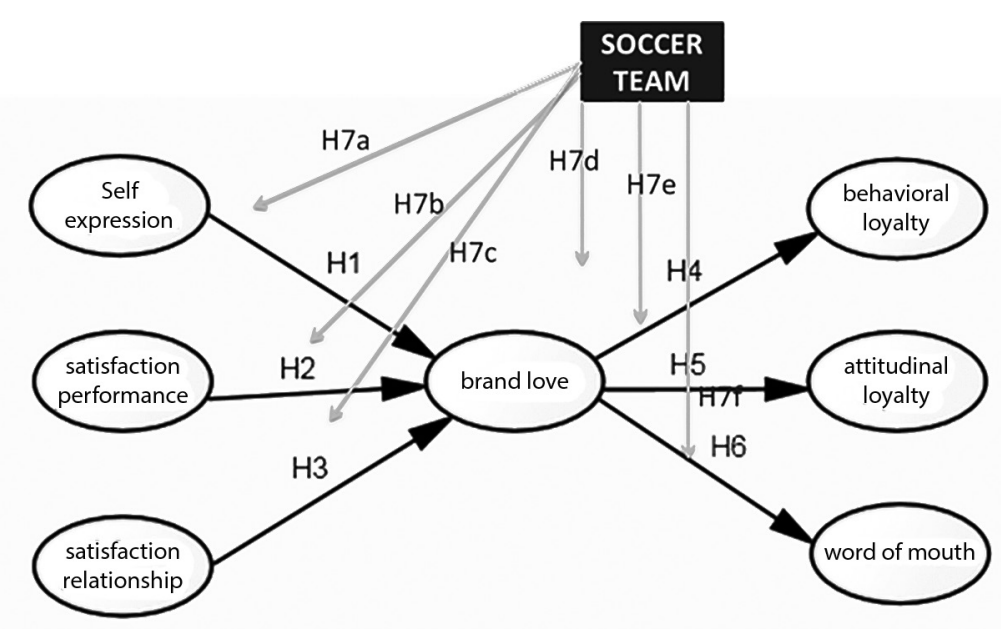

Source: developed by the authors

Figure 1. Research hypotheses

For this purpose, we analyze satisfaction from the point of view of the football team's performance, according to criteria proposed by Matsuoka, Chelladurai and Harada (2003). Thus, the present study examines satisfaction through these two prisms and to this end, works with the following hypotheses:

- H2: Satisfaction with the performance directly and positively affects brand love;

- H3: Satisfaction with the relationship directly and positively affects brand love.

We understand satisfaction with the performance as the cumulative reaction with the fan's various experiences with the games watched over a certain period of time, either in person or at a distance (SANTANA, 2009). This definition was adapted from the one used by Matsuoka, Chelladurai and Harada (2003), where the fan's reaction are verified after the occurrence of only one game.

As for the satisfaction with the relationship, we opted for the adaptation of the satisfaction concept by Anderson, Fornell and Lehmann (1994), conducted by Santana (2009) for the research application field - in this case, we apply it to the football area: "the overall assessment made by the consumer over time, based on the total experience of consumption of footballing goods/services and interactions with the team".

Another construct that relates to brand love, though as consequent, is loyalty, which is understood as the repetition of the buying act by a particular person who is not concerned to learn about competing brands (PRADO, 2004). Similar to satisfaction, loyalty can be present itself in different prisms. In this study, we will use the perspective of behavioral loyalty, understood as the purchasing behavior over already made purchases as well as on future intentions (BAUER; SAUER; EXLER, 2005). We will also try to understand the relationship of brand love with the attitudinal loyalty, i.e., consumer engagement with the product or brand that generates concrete attitudes in them (BAUER; SAUER; EXLER, 2005). Thus, two more hypotheses of this study emerge:

- H4: Brand love directly and positively affects the behavioral loyalty;

- H5: Brand love directly and positively affects the attitudinal loyalty.

As our last consequent construct we have the positive word of mouth. Guided by the study by Carroll and Ahuvia (2006) which proved that brand love affects the positive word of mouth, understood as the degree to which consumers emphasize and "promote" the brand to others (WESTBROOK, 1987); this study considers that consumers who are lovers of their teams' brand will have a greater predisposition to emphasize their qualities to people close to them, and, therefore, our sixth hypothesis is: 
BBR

14,3

276

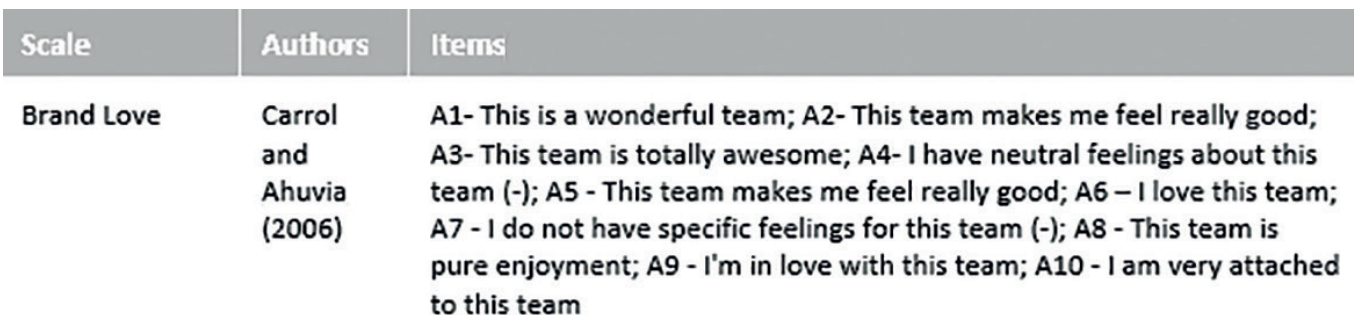

\begin{tabular}{|l|l|}
\hline $\begin{array}{l}\text { Self-expressive } \\
\text { brand }\end{array}$ & $\begin{array}{l}\text { Carrol } \\
\text { and } \\
\text { Ahuvia } \\
\text { (2006) }\end{array}$ \\
\hline $\begin{array}{l}\text { Positive word } \\
\text { of mouth } \\
\text { communication }\end{array}$ & $\begin{array}{l}\text { Carrol } \\
\text { and } \\
\text { Ahuvia } \\
\text { (2006) }\end{array}$ \\
\hline $\begin{array}{l}\text { Attitudinal } \\
\text { loyalty }\end{array}$ & $\begin{array}{l}\text { Bauer et } \\
\text { al (2005) }\end{array}$ \\
\hline $\begin{array}{l}\text { Behavioral } \\
\text { loyalty }\end{array}$ & $\begin{array}{l}\text { Bauer et } \\
\text { al (2005) }\end{array}$ \\
\hline
\end{tabular}

SI1-This team symbolizes the kind of person I really am; SI2- This team reflects my personality; SI3 - This team is an extension of my way of being; SS1 - This team contributes to my image; SS2 - This team contributes to the social role that I represent; SS3 - This team has a positive impact on what others think of me; SS4 - This team improves the way society sees me

C1 - I have recommended this team to several people; C2 - I speak well of this team with my friends; $\mathrm{C} 3-\mathrm{I}$ try to spread good news about this team; $\mathrm{C} 4-\mathrm{I}$ do a lot of advertising for this team , through a positive word of mouth

LA1 - I am a true fan of the team which I support; LA2 - I am very committed to the team which I support; LA3 - There is nothing that could change my commitment to my team; LA4 - I will not change my appearance for the team which I support, just because my team may no longer succeed; LA5 - I would defend my team in public, even if it causes problems; LA6 - I would not support another team just because my friends try to convince me to do that

LC1 - I have often gone to matches to watch my team or have watched them often on television; LC2 - I will often go to matches to watch my team or I will watch them often on television; LC3 - I have often followed, reports on players, coaches and my team's leaders; LC4 - I will often follow, reports on players, coaches and my team's leaders; LC5 - I have bought my team's licensed products; LC6 - I will buy my team's licensed products; LC7 - I have often worn my team's colors or shield; LC8 - I will often wear my team's colors or shield

\begin{tabular}{|c|c|c|}
\hline $\begin{array}{l}\text { Satisfaction } \\
\text { with the } \\
\text { performance }\end{array}$ & $\begin{array}{l}\text { Matsuoka } \\
\text { et al } \\
(2003)\end{array}$ & $\begin{array}{l}\text { SD1 - Satisfaction with the results achieved by the team for which one } \\
\text { supports; SD2 - Satisfaction with the quality of the team's game for } \\
\text { which one supports; SD3 - Satisfaction with the quality of the games in } \\
\text { which the team participated for which one supports, including their } \\
\text { opponents in this analysis }\end{array}$ \\
\hline $\begin{array}{l}\text { Satisfaction } \\
\text { with the } \\
\text { relationship }\end{array}$ & $\begin{array}{l}\text { Prado } \\
\text { (2004) }\end{array}$ & $\begin{array}{l}\text { SR1 - How do you evaluate your satisfaction with your relationship with } \\
\text { the team XX? (very dissatisfied to completely satisfied); SR2 - How do } \\
\text { you evaluate your relationship with the team XX? (far below expectation } \\
\text { X well above expectations); SR3 - How do you evaluate your relationship } \\
\text { with the team XX? (far from ideal X very close to the ideal); SR4 - I'm } \\
\text { really enjoying supporting XX (totally disagree } x \text { totally agree) }\end{array}$ \\
\hline
\end{tabular}

Source: adapted from Santana (2009)

Figure 2. Scales used in research.

- H6: Brand love directly and positively affects the positive word of mouth communication.

From the moment that psychology took an interest to better understand love, studies emerged seeking its measurement, such as the ones by Rubin (1970) and Hatfield and Sprecher (1986). As a result of these studies, there have been studies that show different types or styles of love (NETO, 1993; KIM; HATFIELD, 2004) and especially that there are factors (moderators) which interfere in the forms and intensity of love. Among these factors 
that stand out, we have gender (HAZAN; SHAVER, 1987; HENDRICK; HENDRICK, 1995; MONTGOMERY; SORELL, 1998), age (MONTGOMERY; SORELL, 1998) and even cultural aspects (KIM; HATFIELD, 2004).

Thus, psychological studies show that not all love the same way and for the same reasons. Starting from this observation, this study aims, in an exploratory manner, to identify whether the football team can be a moderating factor of love. Therefore, we have created the following hypotheses:

- H7: The football team chosen by fans affects the relationship between: selfexpression of the brand and brand love $(\mathrm{H} 7 \mathrm{a})$; satisfaction with the performance and the brand love $(\mathrm{H} 7 \mathrm{~b})$; satisfaction with the relationship and the brand love (H7c); brand love and behavioral loyalty (H7d); brand love and attitudinal loyalty (H7e); brand love ad positive word of mouth communication (H7f).

\section{METHOD}

The study is quantitative and descriptive, using measurement models used and tested earlier: antecedents and consequents of Brand Love of the football team by Santana (2009). The survey was conducted only with fans of the two teams involved (Sport Club Internacional e Grêmio Futebol Portoalegrense), the two main teams in Rio Grande do Sul state with the largest fan base.

Data collection took place in September 2011 and was conducted via e-mails sent to undergraduate and graduate students in Business Administration, and via social networks, which made the sample wider and more heterogeneous. We chose to use electronic means due to its ease and convenience, as the respondent can fill out the form sent when it is more convenient for them.

The questionnaire was relatively long, and so, several questionnaires were discarded. Finally, 270 valid questionnaires remained, that is, fully completed and whose respondents were supporters of Grêmio or Internacional. We considered that the data collection period was favorable, because at that time, the two teams presented relatively similar performance, they were taking part in Brazilian Championship and held intermediate positions on the ranking (they did not run the risk of relegation nor were in the promotion area for the Copa Libertadores). At that moment of the championship, the Internacional team was about six positions ahead of the Grêmio team in the Brazilian Championship table.

The data collection instrument was based on the scales shown in Figure 2 and measured the following constructs: brand love, self-expression, satisfaction with the performance, satisfaction with the relationship, attitudinal loyalty, behavioral loyalty and positive word of mouth communication. We also included five variables on respondents' profile, which resulted in an instrument with a total of 47 questions.

The statistical procedures used were divided into six stages. In stage 1, we used the percentage and frequency analysis to characterize the survey respondents. In stage 2 , we aimed at the construction of the structural model that would be tested later and, therefore, Confirmatory Factor Analysis procedures were used. In this stage, the instrument was purified (with the exclusion of some variables) and the reliability and validity of scales we evaluated. In stage 3, the correlations were made between constructs aimed to prove the discriminant validity of the model.

In stage 4, which works with Structural Equations was subdivided. Before performing the verification of the structural adjustment model (generated in stage 2), we used the mahalanobis' distance to prove the existence of extreme cases (no outlier was greater than 1.5 quartile deviation). Then, we performed the KS test to identify the normality of the results, and we found that some items did not present normality (which could affect the model fitting). The one-dimensionality of the model was confirmed by the values of the standardized 
BBR

14,3

278

residuals lower than $2.58(p<0.05)$. The convergent validity was also tested and confirmed, as the standardized factor loadings were significant at the 0.01 level ( $t$-value $\geq 2.33$ ). And by comparing the extracted variance of the dimension and their shared variance, we identified that there is a positive discriminant validity. In the Confirmatory Factor Analysis (CFA). The model fitting was identified through baseline comparison indices and the RMSEA. In stage 4, the proof of hypotheses of causal relationships between the constructs took place, through indices of significance levels of the performed regressions (first six hypotheses).

To identify the choice of the football team as moderating factors, we performed two statistical procedures. In stage 5, basic statistical analysis were made (means and standard deviation), aiming to identify whether there were differences in perceptions between the fans of both teams (T test). In the last stage of the statistical procedures, stage 6 , we sought to confirm the influence of gender as a moderating factor of causal relationships, and therefore, the sample was divided according to each football club: Grêmio $(n=165)$ and Internacional $(n=105)$ fans. Through the structural equation modeling, the remaining six hypotheses were tested, and then, the Invariance Test, which aims to confirm that the model behavior is influenced differently between subsamples (BYRNE, 2009).

\section{RESULTS}

The main profile filter of the sample was the football team for which the respondent supported. In this sense, the sample consisted of 165 Grêmio fans and 105 Internacional fans, that is, Grêmio supporters were predominant (61.1\%). We note that the sample consisted of 125 women and 145 men, thus, the sample was well distributed with $46.5 \%$ of respondents female and $53.7 \%$ male. In terms of age groups, the results were: $25.6 \%$ from 18 to 25 years; $47.0 \%$ from 26 to 35 years; $11.1 \%$ from 36 to 40 years; $3.7 \%$ from 41 to 45 years; and $12.6 \%$ from 46 to 50 years. Finally, in relation to the educational level, the results were: $1.1 \%$ incomplete high school; $0.7 \%$ complete high school; $65.2 \%$ incomplete higher education; $10.0 \%$ complete higher education; $9.6 \%$ incomplete graduation; e $13.3 \%$ complete graduation.

Following the procedures suggested by Hair et al (2005), for a pre-evaluation of the model (formed by the constructs antecedents and consequents of brand love), we performed a Confirmatory Factor Analysis with Varimax rotation, and the exclusion of items with loads lower than 0.50 . In the brand love construct, the variable A8 was excluded (This is team is pure joy), and in the attitudinal loyalty construct the variables LA4 were excluded (I will not leave my team's fan base from, just because my team may no longer succeed) and LA6 (I would not leave my team's fan base for another team only because my friends tried to convince me), since all have factor loading lower than 0.50 .

The brand love construct had nine variables that explained $61.54 \%$ of the total variance, presented a KMO of 0.909 and Cronbach's alpha of 0.592. The self-expression construct was formed by three interpersonal expression variables and four variables measuring social expression explain $89.91 \%$ of the total variance, KMO of 0.743 and Cronbach's alpha of 0.943 . The satisfaction with the performance construct was formed by three variables that explain $87.51 \%$ of the total variance, KMO of 0.766 and Cronbach's alpha of 0.926 . The satisfaction with the relationship construct was formed by four variables that explain $75.64 \%$ of the total variance, KMO of 0.838 and Cronbach's alpha of 0.891 . The behavioral loyalty was measured with eight items that explain $71.06 \%$ of the total variance, KMO of 0.802 and Cronbach's alpha of 0.941 . The attitudinal loyalty was formed by four items that explain $66.65 \%$ of the total variance, KMO of 0.767 and Cronbach's alpha of 0.822 . And the positive word of mouth communication construct was measured by using four variables that explain $77.57 \%$ of the total variance, KMO of 0.824 and Cronbach's alpha of 0.897 . All this information is presented in Table 1. 
Table 1. Statistical results of the used constructs.

\begin{tabular}{lccccc}
\hline Scale & KMO & Variance & Reliability & \multicolumn{2}{c}{ Descriptive Statistics } \\
\hline & & (AVE) & & Mean & Deviation \\
Brand Love & 0.909 & $61.54 \%$ & 0.592 & 3.470 & 0.482 \\
Self-expression & 0.743 & $89.91 \%$ & 0.943 & 2.767 & 0.928 \\
Satisf. w/ the performance & 0.766 & $87.51 \%$ & 0.926 & 4.125 & 1.445 \\
Satisf. w/ the relationship & 0.838 & $75.64 \%$ & 0.891 & 6.876 & 1.983 \\
Behavioral loyalty & 0.802 & $71.06 \%$ & 0.941 & 4.702 & 1.556 \\
Attitudinal loyalty & 0.767 & $66.61 \%$ & 0.822 & 4.983 & 1.388 \\
Word of mouth & 0.824 & $77.57 \%$ & 0.897 & 3.783 & 0.942 \\
\hline
\end{tabular}

At the end of the Confirmatory Factor Analysis stage the initial structural model was generated, validated by the Confirmatory Factor Analysis and used to confirm the hypotheses. The structural model is comprised of the three antecedents constructs of brand love (selfexpression, satisfaction with the performance and satisfaction with the relationship), the brand love construct and three consequents constructs of brand love (attitudinal loyalty, behavioral loyalty and positive word of mouth communication). The model presents construct validity (all factor loadings above 0.60 ) and satisfactory reliability (Cronbach's alpha greater than 0.60).

With this information, the Pearson correlations between the constructs were calculated. This procedure aims to identify the discriminant validity of the proposed model. Table 2 presents these results. The data demonstrate that all correlations were significant. According to Hair et al (2005), the discriminant validity is confirmed when the correlations do not reach the maximum limit of 0.90 , and in this model the highest correlation reached the value of 0.709 (among the attitudinal loyalty and behavioral loyalty constructs). Another analysis that is needed is to compare the correlations squared value (which are placed at the top of the matrix presented in Table 2) with the variance extracted by each construct - AVE (Table 1). As observed, none of the high correlations squared values were greater than their respective variance values explained by the construct. Thus, the discriminant validity of the model is confirmed.

The absence of extreme cases was analyzed by the box diagram, because none of the discrepant values stood at 1.5 or more quartile deviations - mahalanobis distance of the upper or lower quartile (LOPES, 2005). The KS test and the Q-Q and P-P graphs demonstrated that some items do not show normal distribution, which may affect the model fitting.

In the Confirmatory Factor Analysis we used the maximum likelihood method for the estimation of parameters and focus was given to the baseline comparison indices in the verification of the global model fit.

Table 2. Correlations for the analysis of the discriminant validity of the model.

\begin{tabular}{lccccccc}
\hline & AM & BB & LA & LC & SD & SR & AEx \\
\hline Brand Love & 1 & 0.345 & 0.425 & 0.364 & 0.123 & 0.294 & 0.285 \\
Word of mouth & $0.587^{* *}$ & 1 & 0.388 & 0.317 & 0.107 & 0.209 & 0.271 \\
Attitudinal loyalty & $0.652^{* *}$ & $0.623^{* *}$ & 1 & 0.503 & 0.109 & 0.292 & 0.279 \\
Behavioral loyalty & $0.603^{* *}$ & $0.563^{* *}$ & $0.709^{* *}$ & 1 & 0.106 & 0.206 & 0.279 \\
Satisf. Performance & $0.351^{* *}$ & $0.327^{* *}$ & $0.330^{* *}$ & $0.325^{* *}$ & 1 & 0.436 & 0.048 \\
Satisf. Relationship & $0.542^{* *}$ & $0.457^{* *}$ & $0.540^{* *}$ & $0.454^{* *}$ & $0.660^{* *}$ & 1 & 0.099 \\
Self-expression & $0.534^{* *}$ & $0.521^{* *}$ & $0.528^{* *}$ & $0.528^{* *}$ & $0.220^{* *}$ & $0.314^{* *}$ & 1 \\
\hline
\end{tabular}

** Significant correlations at the 0.01 level. 
BBR

14,3
Figure 3 shows the final structural model whose fit indices were: chi-square $=1232.003$; degrees of freedom $=615 ; \chi^{2} / \mathrm{df}=2.00 ; \mathrm{NFI}=0.870 ; \mathrm{RFI}=0.898 ; \mathrm{IFI}=0.930 ; \mathrm{TLI}=0.924$; $\mathrm{CFI}=0.930$ and $\mathrm{RMSEA}=0.061$. According to Hair et al (2005), suitable values for model fitting are RMSEA lower than $0.080, \chi^{2} / \mathrm{df}$ up until 5.00 and values greater than 0.900 for the other indices. Thus, the model presented satisfactory values that confirm the fitting of the final structural model.

The initial structural model demonstrated that two of the behavioral loyalty construct variables showed significant correlations with more than one variable. The LC1 variable (I often go to stadiums to watch my team's matches or I have often watched them play on television) presented correlation of 0.649 with the LC2 variable (I will go often to the stadium to watch my team's matches or I will watch them often on television) and correlation of -0.444 with variable LC4 (I will often follow, reports on players, coaches and my team's leaders), a fact that indicated the possible exclusion of the LC1 variable. The LC6 variable (I will buy my team's licensed products) was also subject to exclusion, as it correlated with the LC5variable (I have been buying my team's licensed products) on a 0.685 degree and with the LC8 variable (I will often wear my team's colors or shield) on a 0.150 degree. Therefore, respondents identified similarities between the statements that measured these variables. Thus, we proceeded with the exclusion of the LC1 and LC6 variables, generating an improvement in the fitting of the structural model.

Following the suggestions of the indices of modification, suggested by actual statistical software, correlations inclusions between some variables were tested. Significant correlations that were kept in the final model were among the constructs: satisfaction with the performance and satisfaction with the relationship (correlation of 0.736 ); behavioral loyalty and attitudinal loyalty (correlation of 0.452 ), both justified and corroborated by the literature. Correlations between variables occurred in the following pairs: LC7 - I have often worn my team's colors or shield - and LC8 - I will often wear my team's colors or shield - (0.857 correlation); SS1 - This team contributed with my image - and SS2 this team has contributed for the social role that I represent - (0.584 correlation); SS3 - This team has a positive impact on what others think about me - and SS4 - This team improves the

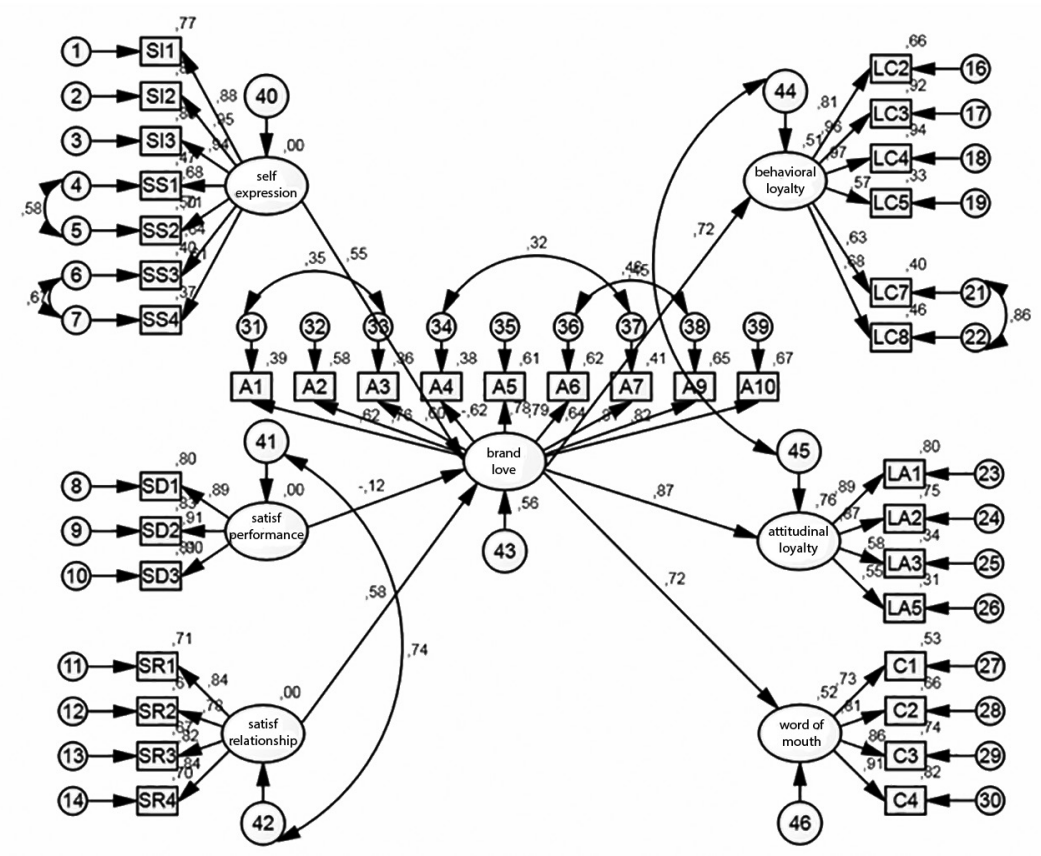

Source: developed by the authors

Figure 3. Validated global model. 
way society sees me - (0.671 correlation); A6 and A9 ( 0.459 correlation); A1 - This is a wonderful team - and A3 - This team is totally impressive - (0.352 correlation); A4 - I have neutral feelings in relation to this team - and A7 - I have no specific feelings for this team - (0.322 correlation). All correlations occurred between variables of the same construct, confirming the difference perceived by the respondents between the measured constructs in the study.

Convergent validity was proven, because all items have standardized factor loadings significant at the 0.01 level ( $\mathrm{t}$-value $\geq 2.33$ ). No value presented $\mathrm{t}$-value lower than the limit, and the lowest value was 9.432 for the item A4 (I have neutral feelings in relation to this team). To identify the discriminant validity, we used the comparison procedure between the extracted variance of the dimension and its shared variance, and the results showed that all were extracted variances greater than the shared variance, thus demonstrating that the discriminant validity is positive. The one-dimensionality of the model is analyzed through the values of standardized residuals (error), and as shown in Figure 3, all the values are lower than $2.58(\mathrm{p}<0.05)$, which demonstrates a one-dimensionality.

After model validation, we went on to test the research hypotheses. Table 3 shows the results of structural equation modeling that analyzes the relationship between the antecedents constructs of brand love (self-expression, satisfaction with the performance and satisfaction with the relationship) and the consequent constructs of brand love (behavioral loyalty, attitudinal loyalty and positive word of mouth).

The first hypothesis (H01) asserted that the brand's self-expression directly and positively affects brand love, and the results corroborate with this statement, since there was a significant causal relationship of $55.4 \%(\beta=0.554 ; p=0.000)$. The second hypothesis assumed that satisfaction with the performance directly and positively affects brand love, however, the data show an inverse relationship, that is, the worse the team's performance is, the greater the love for it, though this hypothesis was not confirmed at a $5 \%$ significance level $(\beta=-0.119 ; p=0.142)$.

In the third hypothesis, the proposal was to identify whether satisfaction with the relationship directly and positively affects brand and the research confirms that the relationship is significant at the $58 \%$ level $(\beta=0.580 ; p=0.000)$. Hypothesis four was also confirmed, and the results indicate a positive causal relationship between brand love and behavioral loyalty in a relationship of $72 \%(\beta=0.717 ; p=0.000)$. In hypothesis five, it was claimed that brand love directly and positively affects the attitudinal loyalty, and the results demonstrated that the hypothesis is correct the dependency relationship is positive and very strong, with $87 \%$ dependency $(\beta=0.874 ; p=0.000)$. Finally, the sixth hypothesis states that brand love directly and positively affects the positive word of mouth communication, the relationship found was of $72 \%$, significant at a $5 \%$ level $(\beta=0.712 ; p=0.000)$, thus confirming the hypothesis.

In continuing the analysis, we calculated the $\mathrm{T}$ test for the identification of mean differences between the fans of Grêmio and Internacional. To this end, we proceeded to the calculation of the constructs' means. Significant differences in the following constructs

Table 3. Hypothesis test.

\begin{tabular}{lcllccc}
\hline Hyp. & \multicolumn{2}{c}{ Relationship } & & $\beta$ & Sig. & Conclusion \\
\hline H1 & self-expression & $\rightarrow$ & brand love & 0.554 & $* * *$ & Not rejected \\
H2 & satisfaction perform. & $\rightarrow$ & brand love & -0.119 & 0.142 & Rejected \\
H3 & satisfaction relat. & $\rightarrow$ & brand love & 0.580 & $* * *$ & Not rejected \\
H4 & brand love & $\rightarrow$ & behavioral loya. & 0.717 & $* * *$ & Not rejected \\
H5 & brand love & $\rightarrow$ & attitudinal loya. & 0.874 & $* * *$ & Not rejected \\
H6 & brand love & $\rightarrow$ & word of mouth & 0.721 & $* * *$ & Not rejected \\
\hline
\end{tabular}


were confirmed: brand love (Internacional mean $=3.55$; Grêmio mean $=3.42 ; p=0.033$ ); attitudinal loyalty (Internacional mean $=5.02$; Grêmio mean $=4.84 ; p=0.026$ ); behavioral loyalty (Internacional mean $=4.95$; Grêmio mean $=4.54 ; p=0.034$ ); satisfaction with the performance $($ Internacional mean $=5.17$; Grêmio mean $=3.46 ; p=0.000)$; and satisfaction with the relationship (Internacional mean $=7.78$; Grêmio mean $=6.30 ; p=0.000$ ). In all constructs the means attributed by Internacional fans was greater than that of Grêmio fans indicating greater concordance of the Internacional fans in relation to the statements proposed in the survey instrument.

In order to verify the influence of the football team moderating factor in the relationship between the antecedents and consequents constructs of brand love and, therefore, test the other hypotheses of the study, the data were separated into two groups: Grêmio fans ( $\mathrm{n}=$ $165)$ and Internacional fans $(\mathrm{n}=105)$. Thus, the structural models were generated, and the hypothesis analysis was made by comparing both. These results are shown in Table 4 .

The hypothesis that measures the impact of the choice of the football team in the relationships of the brand love construct was divided into six secondary hypotheses. The first one (H7a) claimed that the football team chosen by fans affects the relationship between the brand's self-expression and brand love. The results showed that the relationship was significant in both teams and was strongest in Grêmio fans $(\beta=0.679 ; p=0.000)$ than in Internacional fans $(\beta=0.298 ; p=0.005)$, which leads us to try and confirm the hypothesis through the invariance test.

The next hypothesis $(\mathrm{H} 7 \mathrm{~b})$ states that the satisfaction with the performance positively impacts brand love, and the results demonstrated that the relationship was significant only among Internacional fans $(\beta=-0.295 ; p=0.038)$, however, we found an inverse relationship, that is, the lower the satisfaction with the team's performance, the greater the brand love. As among the Grêmio supporters the relationship was not significant $(\beta=-0.097 ; p=0.2510)$, the hypothesis is not rejected.

In hypothesis $\mathrm{H} 7 \mathrm{c}$ the statement that the satisfaction with the relationship positively impacts brand love, though in a different manner among supporters of both teams, we identified that both relationships were significant. Among Internacional fans, the result the result of the relationship was superior $(\beta=0.792 ; p=0.00)$, and it was also found among Grêmio fans, however, more weakly $(\beta=0.469 ; p=0.00)$. Thus, to confirm the veracity of the hypothesis it is necessary to perform the invariance test (which will be presented in the sequence).

Table 4. Comparison between the football teams.

\begin{tabular}{|c|c|c|c|c|c|c|c|}
\hline Hyp. & Rel & tions & & Team & $\beta$ & Sig. & Conclusion \\
\hline \multirow{2}{*}{$\mathrm{H} 7 \mathrm{a}$} & \multirow{2}{*}{ self-expression } & \multirow{2}{*}{$\rightarrow$} & \multirow{2}{*}{ brand love } & Grêmio & 0.679 & $* * *$ & \multirow{2}{*}{ Not rejected } \\
\hline & & & & Internacional & 0.298 & 0.005 & \\
\hline \multirow{2}{*}{$\mathrm{H} 7 \mathrm{~b}$} & \multirow{2}{*}{ satisfaction perform. } & \multirow{2}{*}{$\rightarrow$} & \multirow{2}{*}{ brand love } & Grêmio & -0.097 & 0.251 & \multirow{2}{*}{ Not rejected } \\
\hline & & & & Internacional & -0.295 & 0.038 & \\
\hline \multirow{2}{*}{$\mathrm{H} 7 \mathrm{c}$} & \multirow{2}{*}{ satisfaction relat. } & \multirow{2}{*}{$\rightarrow$} & \multirow{2}{*}{ brand love } & Grêmio & 0.469 & $* * *$ & \multirow{2}{*}{ Not rejected } \\
\hline & & & & Internacional & 0.792 & $* * *$ & \\
\hline \multirow{2}{*}{$\mathrm{H} 7 \mathrm{~d}$} & \multirow{2}{*}{ brand love } & \multirow{2}{*}{$\rightarrow$} & \multirow{2}{*}{ behavioral loyalty } & Grêmio & 0.772 & $* * *$ & \multirow{2}{*}{ Not rejected } \\
\hline & & & & Internacional & 0.605 & $* * *$ & \\
\hline \multirow{2}{*}{$\mathrm{H} 7 \mathrm{e}$} & \multirow{2}{*}{ brand love } & \multirow{2}{*}{$\rightarrow$} & \multirow{2}{*}{ attitudinal loyalty } & Grêmio & 0.891 & $* * *$ & \multirow{2}{*}{ Rejected } \\
\hline & & & & Internacional & 0.805 & $* * *$ & \\
\hline \multirow{2}{*}{$\mathrm{H} 7 \mathrm{f}$} & \multirow{2}{*}{ brand love } & \multirow{2}{*}{$\rightarrow$} & \multirow{2}{*}{ word of mouth } & Grêmio & 0.722 & $* * *$ & \multirow{2}{*}{ Rejected } \\
\hline & & & & Internacional & 0.665 & $* * *$ & \\
\hline
\end{tabular}


The next hypothesis (H7d) aimed at identifying whether the choice of the football team interferes in the relationship that brand love positively impacts in behavioral loyalty, and the results were $77.2 \%$, with significance of 0.000 , for Grêmio supporters and $60.5 \%$, with significance of 0.000 , for Internacional fans. Preliminary results indicate that the relationship is stronger among Grêmio fans, however it is necessary to perform the invariance test to confirm the hypothesis.

Hypothesis H7e proposed that the choice of the football team influences the relationship between brand love and it positive impact in the attitudinal loyalty. The results show that the relationship is significant for both, Grêmio fans $(\beta=0.891 ; p=0.00)$ as for Internacional fans $(\beta=0.805 ; p=0.00)$, being more pronounced among the Grêmio fans.

As the last hypothesis of the study (H7f), it pointed out that the choice of the football team would work as a moderating factor in the relationship between brand love and its positive impact on positive word of mouth communication. This relationship was significant in both cases, being higher in Grêmio fans $(\beta=0.722)$ than among Internacional fans $(\beta=0.665)$. So, it is necessary to perform the invariance test to confirm the hypothesis.

The results confirm only one of the hypothesis tested (H7b), as only among fans of the Internacional team the causal relationship was positive between brand love and satisfaction with the performance. To test the other hypotheses, it was necessary to carry out new statistical procedures, i.e., the Invariance Test.

The invariance test consists of, from the base model, calculating the Chi-square $\left(\chi^{2}\right)$ of the restrictive model, detecting whether a significant difference is found $(p=0.000)$. In case it is, the difference between structural models is confirmed. The restrictions were set only for the constructs, without the procedure for each individual variable being conducted (which explains the slight difference between the degrees of freedom $-\Delta \mathrm{df}$ ), and the results were compared with those of the basic model.

The invariance test confirmed that the models are different. For the restrictive model the value of the chi-square test was 3456.9, with 1911 degrees of freedom. Compared to the value of the base model's chi-square, which was 3404.3, the difference found for the chisquare $\left(\Delta \chi^{2}\right)$ was 52.6 with its statistical significance confirmed $(p=0.00)$.

When the restrictions were removed from the relationship between the self-expression and brand love constructs, the invariance test was significant, with value $\Delta \chi^{2}=62.1$, thus confirming the hypothesis $\mathrm{H} 7 \mathrm{a}$. In the relationship between satisfaction with the relationship and brand love, the value of $\Delta \chi^{2}$ was 66.8 , significant at 0.000 , also confirming $H 7 \mathrm{c}$. In the relationship between brand and behavioral loyalty, the invariance test was significant $\left(\Delta \chi^{2}=50.3\right)$, confirming H7d. However, the relationship between brand love and attitudinal loyalty, the value of the chi-square difference was 9.58 and not significant at the $95 \%$ level of significance; therefore, the hypothesis H7 was not confirmed. And, as a final analysis, the restriction between brand love and positive word of mouth communication was tested, with $\Delta \chi^{2}=10.6$ and significance 0.08 , therefore not significant for the $95 \%$ confidence level. Thus, of the hypotheses analyzed by the invariance test, only two (H7e and $\mathrm{H} 7 \mathrm{f}$ ) were not confirmed. Thus, the hypotheses $\mathrm{H7a}, \mathrm{H} 7 \mathrm{c}, \mathrm{H} 7 \mathrm{~d}$ were not rejected through the Invariance Test, and the results of this study confirmed the impact of the choice of the football team as a moderating factor in the relationship between brand love and its antecedents constructs (self-expression, satisfaction with the performance and satisfaction with the relationship) and its consequents constructs (behavioral loyalty, attitudinal loyalty and positive word of mouth communication).

\section{CONCLUSION}

The focus of this study was the brand love of football teams and its relationship with antecedents constructs (self-expression, satisfaction with the performance and satisfaction 
with the relationship) and consequents (behavioral loyalty, attitudinal loyalty and positive word of mouth communication). The work was based on the study by Santana (2009) and it moved towards the inclusion of the football team as a moderating factor.

The research hypotheses were based on other research that confirmed the causal relationships, in the following manner: the study by Carroll and Ahuvia (2006) justified the relationship between self-expression and brand love and between brand love and positive word of mouth; the study by Bauer et al (2005) was used for the proposal of the relationship between the love of football team with attitudinal loyalty and behavioral loyalty; the research by Matsuoka et al (2003) proposes the relationship between brand love and satisfaction with the performance, Prado's (2005), with the satisfaction with the relationship. Finally, the inclusion of the football team as a moderating factor is supported by studies of psychology, such as: and Shaver (1987); and Hendrick (1995); Montgomery and Sorell (1998) and Kim and Hatfield (2004).

In terms of methodology, the study presents limitations: the fact that the sample, when divided into two groups, not being large; comparing only two football teams; submitting a long data collection instrument that makes it difficult to be fulfilled; and data collection basically focused on one city. We consider the strengths of the study to be: the model chosen; the fact that at the time of collection teams presented a similar performance; collection occurred only with declared fans; and the rivalry between the chosen teams.

In terms of results, the first aspect to be highlighted is the robustness of the model proposed by Santana (2009), whose model fitting indices of the Confirmatory Factor Analysis were greater than the desired limits.

The results also served to confirm the hypotheses proposed in the study by Santana (2009), with the exception of the second hypothesis which proposed satisfaction with the performance as an antecedent to brand love. As for the results obtained in other hypotheses, there is a strong association between brand love and attitudinal loyalty $(\beta=0.874)$ which confirms that fans who are lovers of their teams are extremely loyal and demonstrate it through their attitudes. On the other hand, the weaker association occurred between selfexpression and brand love $(\beta=0.554)$; even so, the relationship is considered medium to high. Finally, we observe that the relationships of brand love are stronger with the consequents constructs (behavioral loyalty, attitudinal loyalty and positive word of mouth) than it is with antecedents (self-expression, satisfaction with the performance and satisfaction with the relationship).

Regarding the differences of perceptions between Grêmio and Internacional fans, the study demonstrated two interesting aspects. The first is that, in terms of agreement or disagreement with the statements presented in the models, that is, mean analysis, statistical differences were observed in all constructs, and the means attributed by the International fans were higher than those of Grêmio fans.

The second aspect concerns the inclusion of the team as a moderating factor of brand love, its antecedents and consequents. Only two hypotheses (relationship between brand love and attitudinal loyalty; relationship between brand love and positive word of mouth) did not present significant differences and therefore, were not confirmed.

Thus, we can attest that the football team is a moderating factor in the proposed relationship. A clear example can be seen when some teams are relegated in series (falling from the A to the B division, for example). At such times, some fans show an unconditional love for their teams, which is reflected in full stadiums and incentives to players. However, other teams are forgotten by their fans, being the target of criticism and contempt.

The study also brings contributions to the management of the analyzed times. In this regard, our main findings were: Grêmio fans presented a stronger relationship between selfexpression and brand love; among Internacional fans, the relationship between satisfaction with the performance and brand love is inverse; they present a strong relationship between 
satisfaction with the relationship and brand love; Grêmio fans have a strong relationship between brand love and behavioral loyalty.

In summary, the results show that the managers of the Grêmio Futebol Portoalegrense can focus their marketing actions on self-expression and behavioral loyalty. As for managers of the Sport Clube Internacional, they can work with the satisfaction with the relationship, and, most importantly, create marketing actions when the team is not performing well (since satisfaction with the performance has a significant and inverse relationship with brand love).

As a contribution to the field, we highlight that the study confirmed that sports management must be customized, as each team represents something different for their fans. That is, to strengthen the relationship with their fans, sports marketing managers need to, first of all, know what image the team conveys to fans and what are the main feelings involved in this relationship. In this sense, we suggest two types of research: quantitative research to know the image that the team conveys and qualitative research to better understand the feelings involved in the football team and fan relationship.

\section{REFERENCES}

AHUVIA, A. C. Beyond the extended self: loved objects and consumers identity narratives. Journal of Consumer Research, v.32, p.171-184, 2005.

ANDERSON, E.W.; FORNELL, C.; LEHMANN, D.R. Customer satisfaction, marketshare and profitability: findings from Sweeden. Journal of Marketing, v. 59, n. 2, p.53-66, 1994.

ALBERT, N.; MERUNKA, D.; VALETTE-FLORENCE, P.When consumers love their brands: Exploring the concept and its dimensions. Journal of Business Research, v.61, n.10, p.1062-1075, 2008.

ALBERT, N.; MERUNKA, D.; VALETTE-FLORENCE, P.The feeling of love toward a brand: Concept and measurement. Advances in Consumer Research, v.36, p.300-307, 2009.

ARON, A.; PARIS, M.; ARON, E. N. Falling in love: prospective studies of self-concept change. Journal of Personality and Social Psychology, v.69, p.1102-1112, 1995.

BAUER, H. H.; SAUER, N. E.; EXLER, S. The loyalty of German soccer fans: does a team's brand image matter? International Journal of Sports Marketing \& Sponsorship, v.7, n.1, p.14-22, 2005.

BERGKVIST, L.; BECH-LARSEN, T.Two studies of consequences and actionable antecedents of brand love. Journal of Brand Management, v.17, n.7, p.504-518, 2010.

BRAKUS, J. J.; SCHMITT, B. H.; ZARANTONELLO, L.Brand Experience: What Is It? How Is It Measured? Does It Affect Loyalty? Journal of Marketing, v.73, n.3, p.52-68, 2009.

CAPELO, R. Receitas do Futebol: Como 150 clubes arrecadam dinheiro. p.3, São Paulo. Disponível em: http://www.rodrigocapelo.com/cadastro/?redirect=\%2Fdownloads\%2FRelatorio02-ReceitasdoFutebolRodrigoCapelo.pdf\&subscribed=1. Acesso em: 09 de nov. 2015.

CARROLL, B. A.; AHUVIA, A. C. Some antecedents and outcomes of brand love. Marketing Letter, v.17, p.79-89, 2006.

CHAUDHURI, A.; HOLBROOK, M. B.The chain of effects from brand trust and brand affect to brand performance: the role of brand loyalty. Journal of Marketing, v.65, n.2, p.81-93, 2001.

CORREIA, L.S.S. Emoções manifestadas em relação à marca por consumidores de máquinas agrícolas. Diss. (Mestrado) - Faculdade de Administração, Contabilidade e Economia, Pós-Graduação Economia, PUCRS, 2009.

COULTER, R. A.; PRICE, L. L.; FEICK, L.Rethinking the Origins of Involvement and Brand Commitment: Insights from Postsocialist Central Europe. Journal of Consumer Research, v.30, n.2, p.151-169, 2003.

DELGADO-BALLESTER, E.; MUNUERA-ALEMÁN, J. L.; YAGÜE-GUILLÉN, M. J.Development and validation of a brand trust scale. International Journal of Market Research, v.45, n.1, p.35-53, 2003.

DELGADO-BALLESTER, E.; MUNUERA-ALEMÁN, J. L.Does brand trust matter to brand equity? Journal of Product and Brand Management, v.14, n.3, p.187-196, 2005.

FANTINI, M. J.; GONÇALVES. C. F.; QUIROGA, G. S. Antecedentes do amor a marca e seus impactos nas intenções comportamentais de consumidores: um estudo empírico no setor automotivo. Revista Gestão e Planejamento, v.12, n.1, p.74-94, 2011.

FEHR, B.Prototype analysis of the concepts of love and commitment. Journal of Personality and Social Psychology,v.55, n.4, p.557-579, 1988. 
BBR

14,3

FOURNIER, S.; MICK, D. G. Rediscovering satisfaction. Journal of Marketing, v.63, p.5-23, 1999.

GRISAFFE, D.; NGUYEN, H. Falling in love with brands: An inductive qualitative exploration of pathways to emotional attachment. Advances in Consumer Research, v.36, p.869-870, 2009.

GUTHRIE, M. F.; KIM, H. S.The relationship between consumer involvement and brand perceptions of female cosmetic consumers. Journal of Brand Management, v.17, n.2, p.114-133, 2009.

HATFIELD, E.; SPRECHER, S.Measuring passionate love in intimate relationships. Journal of Adolescence, v.9, n.4, p.383-410, 1986.

HAZAN, C.; SHAVER, P. Romantic love conceptualized as an attachment process. Journal of Personality and Social Psychology,v.52, n.3, p.511-524, 1987.

HENDRICK, S. S.; HENDRICK, C. (1995). Gender differences and similarities in sex and love. Personal Relationships, v.2, n.1, p.55-65.

HIRSCHMAN, E. C.; HOLBROOK, M. B. Hedonic consumption: emerging concepts, methods and propositions. Journal of Marketing, v.46, n.3, p.92-101, 1982.

HOLLEBEEK, L. D. Demystifying customer brand engagement: Exploring the loyalty nexus. Journal of Marketing Management, v.27, n.7-8, p.785-807, 2011.

JOHNSON, M. D.; ANDERSON, E. W.; FORNELL, C. Rational and adaptive performance expectations in a customer satisfaction framework. Journal of Consumer Research, v.21, n.4, p.695-707, 1995.

KIM, J.; HATFIELD, E.Love types and subjective well-being: A cross-cultural study. Social Behavior and Personality, v.32, n.2, p.173-182, 2004.

LAFORET, S.; CHEN, J.Chinese and British consumers' evaluation of Chinese and international brands and factors affecting their choice. Journal of World Business, v.47, n.1, p.54-63, 2012.

MATSUOKA, H; CHELLADURAI, P.; HARADA, M. Direct and interaction effects of team identification and satisfaction on intention to attend games. Sport Marketing Quarterly, v.12, n.4, p.244-253, 2003.

MONTGOMERY, M.J.; SORELL, G.T. Love and dating experience in early and middle adolescence: Grade and gender comparisons. Journal of Adolescence,v.21, n.6, p.677-689, 1998.

NETO, F.Love styles and self-representations. Personality and Individual Differences, v.14, n.6, p.795-803, 1993.

O'CASS, A.; CHOY, E.Studying Chinese generation Y consumers' involvement in fashion clothing and perceived brand status. Journal of Product and Brand Management,v.17, n.5, p.341-352, 2008.

PARK, J. O.; HWANG, J. J.; PARK, E. M. The effect of fashion brand involvement and marketing communication means on building consumer-brand relationship. Advanced Materials Research, v.175, p.1045-1051, 2011.

PANG, J.; KEH, H. T.; PENG, S.Effects of advertising strategy on consumer-brand relationships: a brand love perspective. Frontiers of Business Research in China, v.3, n.4, p.599-620, 2009.

PRADO, P. H. M. A avaliação do relacionamento sob a ótica do cliente: um estudo em bancos de varejo. Tese (Doutorado em Administração de Empresas) - Escola de Administração de Empresas, Fundação Getúlio Vargas, 2004.

PRENDERGAST, G. P.; TSANG, A. S. L.; CHAN, C. N. W.The interactive influence of country of origin of brand and product involvement on purchase intention. Journal of Consumer Marketing, v.27, n.2, p.180$188,2010$.

RICHARDSON, D. R.: MEDVIN, N.: HAMMOCK, G.Love styles, relationship experience, and sensation seeking: a test of validity. Personality and Individual Differences, v.9, n.3, p.645-651, 1988.

RUBIN, Z.Measurement of romantic love. Journal of Personality and Social Psychology, v.16, n.2, p. $265-$ 273, 1970.

SANTANA, E. E. P. O amor à marca e seu relacionamento com algumas variáveis que o antecedem e o sucedem: um estudo sob a ótica de torcedores-consumidores de times de futebol brasileiros. Tese, Universidade Federal do Paraná, 2009.

SELIGMAN, C.; FAZIO, R. H.; ZANNA, M. P. Effects of salience of extrinsic rewards on liking and loving. Journal of Personality and Social Psychology, v.38, p.453-460, 1980.

SICHTMANN, C.An analysis of antecedents and consequences of trust in a corporate brand. European Journal of Marketing, v.41, n.9-10, p.999-1015, 2007.

SHIMP, T. A.: MADDEN, T. J. Consumer-object relations: a conceptual framework based analogously on sternberg's triangular theory of love. Advances in consumer research, v.15, p.163-168, 1988.

SWOBODA, B.; HAELSIG, F.; SCHRAMM-KLEIN, H.; MORSCHETT, D.Moderating role of involvement in building a retail brand.International Journal of Retail and Distribution Management, v.37, n.11, p.952974, 2009. 
THOMSON, M.; MACINNIS, D. J.; PARK C W. The ties that bind: Measuring the strength of consumers' emotional attachment to brands. Journal of Consumer Psychology, v.15, p.77-91, 2005.

TSAI, S. P. Fostering international brand loyalty through committed and attached relationships. International Business Review, v.20, n.5, p.521-534, 2011.

YANNOPOULOU, N.: KORONIS, E.; ELLIOTT, R.Media amplification of a brand crisis and its affect on brand trust. Journal of Marketing Management,v.27, n.5-6, p.530-546, 2011.

YI, Y.; JEON, H.Efects of loyalty programs on value perception, program loyalty, and brand loyalty. Journal of the Academy of Marketing Science, v.31, n.3, p.229-240, 2003.

WHANG, YN-OH; ALLEN, J.; SAHOURY, N.; ZHANG, H. Falling in love with a product: the structure of a romantic consumer-product relationship. Advances in Consumer Research, v.31, p.320-327, 2004. 